\title{
CONDITIONAL DISCONTINUANCE OF CRIMINAL PROCEEDINGS IN THE POLISH LEGAL SYSTEM - THE FIFTY YEARS OF EXPERIENCE AND THE ASSESSMENT OF PROSPECTS FOR FURTHER DEVELOPMENT
}

Summary: This analysis addresses the issue of conditional discontinuance of criminal proceedings in the Polish legal system. The deliberations concern the normative nature of this measure of penal response, its hybrid legal regulation and its evolution during the period of 50 years of its operation. The analysis takes into account current trends in the Polish criminal procedure and the position of conditional discontinuance as a criminal policy instrument in view of the increase in the relevance of consensual forms of criminal procedure. It primarily addresses the procedural regulation of conditional discontinuance contained in the Polish Criminal Procedure Code. The Polish experience in the use of conditional discontinuance as a criminal policy instrument against perpetrators of minor social harmfulness, non-demoralised, with positive prediction shows that the institution has proved itself and should be used more broadly in the practice of the judiciary. The prospects for increasing the use of conditional discontinuance as an effective, due to the modern substantive and procedural penal legislation, measure of combating crime have been discussed.

Key words: $\quad$ conditional discontinuance of criminal proceedings, Polish criminal law, consensual adjudication in criminal matters, non-custodial means of penal response

\footnotetext{
* Hanna Paluszkiewicz, PhD, prof. dr. hab. at the Faculty of Law and Administration, University of Zielona Góra, pl. Słowiański 9, 65-069 Zielona Góra, Poland. E-mail address: h.paluszkiewicz@wpa.uz.zgora.pl. ORCID: https://orcid.org/0000-0001-51988360 .

** Katarzyna Dudka, PhD, prof. dr. hab. at the Faculty of Law and Administration, Maria Curie-Skłodowska University in Lublin, pl. Marii Curie-Skłodowskiej 5, 20-031 Lublin, Poland. E-mail address: katarzyna.dudka@poczta.umcs.lublin.pl. ORCID: https:// orcid.org/0000-0001-5598-5175.
} 


\section{INTRODUCTION}

When a half-century ago - on 19 April 1969, new criminal codes ${ }^{1}$ were passed in Poland, a new, previously unknown institution called conditional discontinuance of criminal proceedings was introduced in the legal system. Despite its procedural name, it was rather a means of penal response, and its fundamental legal framework was set out in the substantive statute. After the initial lack of confidence among legal professionals about the use of conditional discontinuance and concerns about whether it a proper criminal policy measure to combat minor crime, the time has come for its full acceptance and widespread use in practice. This institution has also been well described in the literature and has already been with entwined with considerable case-law. However, it has not been currently, unlike in the Croatian practice, a significant part of criminal policy. Polish experiences indicate that there can be a multitude of causes of this situation.

The inspiration for us to share the observations on conditional discontinuance in Polish law was the text by Vera Glasnović Gjoni and Vlado Sirotić entitled Conditional discontinuance of criminal procedure and practice of the municipal court in Pula - Pola ${ }^{2}$ and the conclusion stated therein that the institution of conditional discontinuance in the criminal law of Croatia is not used in spite of the enormous potential carried by it. Therefore, the problem of conditional discontinuance in Polish law is worth presenting to the Croatian reader, because this year it is 50 years since its introduction. It is thus an opportunity to reflect on the reasonableness of the existence and the degree of use of conditional discontinuance of criminal proceedings as a criminal policy instrument, in particular in view of the growing tendency to settle criminal cases in a consensual way using other forms of substantive adjudication on liability for an offence.

At the outset, it can be argued that conditional discontinuance, whose normative character was initially somewhat unclear to legal scholars and legal professionals, ${ }^{3}$ has become a well-established feature of the Polish criminal law system over the years. It is (and has been) a hybrid institution. Originally conceived as a specific means of penal response to minor crimes and applied to non-depraved offenders with a positive prediction, it was first and foremost an institution of substantive criminal law. It is in the Criminal Code where the grounds and conditions for its application have been specified. Only with time, when this institution "has

$1 \quad$ Ustawa z dnia 19 kwietnia 1969 r. Kodeks karny (Dz.U. z 1969 r., Nr 13, poz. 94), zwany dalej k.k. z 1969 r.; [Act of 19 April 1969 Criminal Code (Journal of Laws 1969, No. 13, item 94), hereinafter referred to as CC of 1969]; Ustawa z dnia 19 kwietnia 1969 r. Kodeks postępowania karnego (Dz.U. z 1969 r., Nr 13, poz. 96), zwany dalej k.p.k. z 1969 r. [Act of 19 April 1969, Criminal Procedure Code (Journal of Laws 1969, No. 13, item 96), hereinafter referred to as CPC of 1969].

2 Journal of law and social sciences of the Law Faculty of University J. J. Strossmayer in Osijek = Zeitschrift für Rechts-und Sozialwissenschaften der Fakultät für Rehtswissenschaften der Universität J. J. Strossmayer in Osijek = Journal des sciences juridiq, Vol. 32, No. 3-4, 2016.

3 A. Marek, Warunkowe umorzenie postępowania karnego, Warszawa 1973; idem, Istota i skutki warunkowego umorzenia postępowania, Państwo i Prawo 1970, vol. 12, p. 948; A. Zoll, Materialnoprawna problematyka warunkowego umorzenia postępowania, Zeszyty Naukowe Uniwersytetu Jagiellońskiego, Prace Prawnicze 1973, no. 62, pp. 10-31; A. Tobis, $Z$ rozważań nad istota warunkowego umorzenia postępowania karnego, Ruch Prawniczy Ekonomiczny i Socjologiczny 1974, no. 4, p. 135; M. Leonieni; W.Michalski, Warunkowe umorzenie postepowania karnego w świetle ustawy i praktyki sq̨dowej, Warszawa 1972, p. 18; J. Skupiński, Warunkowe umorzenie postępowania karnego jako środek polityki karnej prokuratorów i sądów, Studia Prawnicze, 1991, no. 2, p. 23. H. Paluszkiewicz, Ewolucja instytucji warunkowego umorzenia postępowania karnego w prawie polskim, Czasopismo PrawnoHistoryczne 2008, no. 1, pp. 139-161; K. Juszka, Geneza instytucji warunkowego umorzenia postępowania karnego, Studia Prawnoekonomiczne, 2019, no. 46, pp. 25-39. 
grown" into the legal system and when its advantages and disadvantages were revealed ${ }^{4}$, it was noticed that for its proper use as a means of penal response it is necessary to strengthen its procedural base. This part of legal regulation was relatively scarce before 1997 and undoubtedly required further development due to the definitive transfer of powers to adjudicate on conditional discontinuance to the jurisdiction of common courts.

The 50-years experience of existence in the Polish legal system and the use of conditional discontinuance as a criminal policy instrument against non-depraved perpetrators of acts of minor social harmfulness, with positive prediction, provides grounds for claiming that the institution has proved itself and should be used more broadly in the practice of the judiciary. Its advantages (such as certain flexibility in the application of a penal response in connection with subjecting the perpetrator to a probation and defining the "conditions" of renouncing a traditional punishment) allow for recommending conditional discontinuance as one of the forms of adjudication on criminal liability, in fact fitting into a globally growing trend of development of consensual forms of case resolution. As an attempt to encourage the application of conditional discontinuance in the practice of the Croatian judicial system, first of all one should point to the axiological justification of introducing in 1969 the system of conditional discontinuance to the Polish criminal law, the reasons for its normative regulation in two legal acts: the Criminal Code and the Criminal Procedure Code, and the evolution, which this institution of mixed substantive and procedural nature has undergone to date. This is so, since it is now an unquestionable instrument of criminal policy, though in our opinion is not used as frequently as it could be. Perhaps the experience in terms of normative changes shaping the contemporary form of conditional discontinuance and the assessment of the practice of its application in Poland will allow a different look at this institution and its perspectives in the Croatian justice system, encouraging a wider use of this institution as a valuable and effective means of criminal response to certain types of perpetrators and their deeds.

\section{CONDITIONAL DISCONTINUANCE OF CRIMINAL PROCEEDINGS IN THE PERIOD 1969-1997.}

The idea of introducing the conditional discontinuance of proceedings into the Polish Criminal Code stemmed from the need to create such a system of penal measures, which, having regard to the multi-layered stricture of crime, would be effective in combating both minor and the most serious criminal offences. At the same time, this coincided with the crisis of the penalty of imprisonment as an effective means of social reintegration of perpetrators and the need to use other criminal response measures unrelated to the deprivation of the perpetrator of liberty. ${ }^{5}$ Also the retaliatory nature of the Polish criminal law characterised by high severi-

4 Such as e.g. the option of ruling on conditional discontinuance by a non-judicial body or prosecutor, which is no longer possible in a democratic state governed by the rule of law, and ruling by way of a judicial decision, not a judgement, despite using that institution as a response to a prohibited act when committed - A. Gerecka -Żołyńska; P. Mazur; H. Paluszkiewicz, Kilka uwago instytucji warunkowego umorzenia postępowania karnego na tle jej związków z prawem materialnym i formalnym, (in:) Współzależność prawa karnego materialnego i procesowego (eds.) Z. Ćwiąkalski; G. Artymiak, Warszawa 2009, p. 274.

5 H. Paluszkiewicz, Refleksje o perspektywach rozwoju karnoprocesowej regulacji warunkowego umorzenia postępowania karnego, (in) Reforma prawa karnego. Propozycje i komentarze. Księga pamiątkowa Profesor Barbary Kunickiej-Michalskiej, eds J. 
ty, which was also characteristic of the other countries of the Communist bloc of that time, played its part. The result was overcrowded correctional facilities, which in many cases resulted in a situation where convicts started serving their sentences even after a few years from the date of their convictions becoming final.

The search for new solutions that could remedy existing problems led to the emergence of two distinct concepts of leniency for those who committed deeds of minor severity. The first of them assumed an unconditional waiver of sentencing a penalty in the form of the institution of withdrawal from sentencing a penalty (while the guilt was supposed to be still found by the Court in the judgement). The second concept, from which the conditional discontinuance of proceedings eventually emerged, assumed the occurrence of the element of conditionality, not known to the Criminal Code before, in the form of subjecting the perpetrator to probation. ${ }^{6}$ As a result, the conditional discontinuance of proceedings appeared in the Polish Criminal Code, ${ }^{7}$ being, by definition, an institution of substantive law that allows taking, by the prosecutor in pre-trial proceedings or the Court in judicial proceedings, a decision to refrain from sentencing a previously unpunished perpetrator of a criminal offence punishable with imprisonment of up to 3 years.

The conditional discontinuance of proceedings was being applied for a period of probation of 1 to 2 years, where the degree of social consequences of the offence was not significant, the circumstances of its committing were beyond question, and the attitude of the perpetrator, his personal characteristics and existing way of life provide grounds to assume that, despite the discontinuance, he would comply with the legal order, and in particular he would not commit the offence again. In relation to the person against whom the proceedings were conditionally discontinued, duties to be carried out during the probation period could be imposed, e.g. to remedy the damage caused by the crime, apologise the victim, or perform certain works or services of social purpose. Where a criminal offence against property is committed, the imposition of an obligation to remedy the damage was obligatory. The mere conditional discontinuance could have been made conditional upon a guarantee of the social organisation of which the perpetrator was a member, or the team in which he worked, served or studied, or a trustworthy person, that they would endeavour to ensure that the perpetrator adhere the legal order including in particular that he would not commit a crime again (Article $28 \S 1$ of the Criminal Code of 1969).

The criminal proceedings were required to be resumed where the perpetrator evades performing the duties imposed on him, or where he grossly violates the legal order (even before the decision became final), especially where he commits an offence. Once conditionally discontinued, the proceeding could not be resumed later than within 3 months from the conclusion of the period of probation. A positive conclusion of the probation period, which means both the lack of any breach of law in the period and the performance of duties imposed on the perpetrator, was tantamount to the repeal of liability for the crime committed, which entailed the conditional discontinuance of the criminal proceeding.

Jakubowska-Hara; C. Nowak; J. Skupiński, Warszawa 2008, p. 381.

6 B. Kunicka-Michalska, Warunkowe umorzenie postępowania karnego w latach 1970 - 1977, Warszawa 1982, p. 97 et seq.

$7 \quad$ Art. 27 et seq. of the Criminal Code of 1969. 
The substantive ground for the conditional discontinuance was a finding that the circumstances of the crime raise no doubts, in particular about the perpetration by a particular person. Such finding were supposed to be based on the evidence collected during the pretrial proceeding. Even where the conditional discontinuance was applied by the court during the trial proceedings, the court did not carry out an evidence-taking procedure beside the main hearing, and based its decision on the material contained in the files of the pre-trial proceeding. At that time it was being assumed that although the conditional discontinuance of proceedings is not tantamount to conviction, it undermines the principle of presumption of innocence, positively ruling on the perpetration. However, it did not result in the effects of conviction, for example in the sphere of labour law, by allowing the person with regard to whom the proceedings have been conditionally discontinued, to be employed at a position requiring a criminal record clearance.

The assumption that the conditional discontinuance of proceedings breaks the principle of presumption of innocence and is a form of substantive determination of guilt was not logically related to the regulation of granting the power to issue a decision on conditional discontinuance not only to the court but also to the prosecutor at the stage of pre-trial proceedings (Article $284 \S 1$ of the Criminal Procedure Code of 1969). Such a solution seems odd as the modern perspective assumes that only the court, as an independent and impartial body, may rule on criminal liability for a criminal offence. However, just because of the lack of a clearly defined legal nature of the institution and its explicit recognition by the legislature as a means of criminal response, pre-trial proceedings used to be conditionally discontinued, which practically ruled out the judicial way of determination of liability for the offence committed. Therefore, under the legislation in force at that time, it was a procedural institution of an opportunistic nature, ${ }^{8}$ used by the prosecutor as a form of renouncement of criminal prosecution, which, however, due to the obligation to remedy the damage caused by the offence, could also satisfy the victim. However, a simplified procedure of appeal from the prosecutor's decision was provided for, as the suspect had the right to oppose within 7 days of service of the copy of the decision on conditional discontinuance. The victim could appeal against the "conditions" of the conditional discontinuance. Once the opposition was lodged, the decision lost its effect and the proceedings were continued. This often meant the continuation of the pre-trial proceedings and the bringing in of the indictment, the hearing and issuance of the sentence.

As mentioned above, since the beginning of its existence in the Polish system, the conditional discontinuance was a hybrid legal construct, and the rules governing the conditions and grounds for its application were laid down in the substantive law (Criminal Code), and those governing the procedure for the application of conditional discontinuance in the procedural criminal law (Criminal Procedure Code). The procedural rules contained in the Criminal Procedure Code of 1969 constituted a specific complement to the norms of criminal substantive law by specifying the manner of proceeding about the conditional discontinuance, the bodies authorised to rule it and the form of procedural decision. However, when assessing the scope of the criminal procedural rules contained in the Penal Procedure Code of 1969, it must be stated

8 Under the legislation currently in force, the Criminal Procedure Code of 1997, conditional discontinuance is no longer of such a nature, since other institutions with a clearly opportunistic purpose, such as the so-called "absorption discontinuation" (Article $11 \mathrm{CPC}$ ) used by the public prosecutor when he conducts at least two proceedings against the same offender, one of whom relates to a minor act punishable by a small penalty while the other is a serious act for which the suspect may be punished by a penalty which would in practice "absorb" the lesser penalty which makes the criminal proceedings in this case ungrounded. 
that these were exceptionally scarce. For example, they did not specify the forum on which the decision on conditional discontinuance of criminal proceedings is to be taken (whether hearing or sitting), allowing a decision on conditional discontinuance to be made both in the form of a decision and judgement, and only the case-law and statements of the scholarly opinion have developed certain, though not always perfect, rules on this subject. Of particular importance was the entrusting to non-judicial authorities of the application of conditional discontinuance, which constitutes a specific, but still criminal-law response to a criminal offence, and to rule on that measure in the non-trial proceedings, without the participation of the court, which currently is unimaginable in view of Poland's presence in the European system and the right to fair trial under the European Convention on Human Rights.

It must be admitted, however, that conditional discontinuance of proceedings in Poland in the first years of its presence in the legal system proved effective as an instrument of criminal policy. ${ }^{9}$ Almost from the beginning of their applicability (1 January 1970), the provisions on conditional discontinuance were applied in practice, and prosecutors and courts increasingly used this institution in relation to perpetrators of minor criminal offences who committed a prohibited act for the first time. It was noticed that it was a perfect alternative to short-term penalties and penalties not involving imprisonment (fines and limitation of liberty), in a situation where the circumstances of the case and the offender's attitude indicated that even such penalties would be too severe, which justified the introduction of this institution into the Polish law. Significant was also the fact that overcrowded correctional facilities were relieved, which made it possible to shorten the time between the sentence becoming final and the start of serving the sentence by perpetrators sentenced to imprisonment.

Another important element determined the specific "popularity" of the use of conditional discontinuance of proceedings. Before 1997, there was no institution in Polish criminal law which would allow for a consensual settlement of a case (i.e. the equivalent of a modern conviction without a trial or voluntary submission to a penalty without conducting evidence-taking proceedings at a trial). The opinion that conditional discontinuance of proceedings is an effective means of legal response to a crime committed in the case of deeds of minor importance, providing also for a certain form of compensation for the victim, resulted in the fact that this institution became part of the Polish legal system for good, and it found its place again among new, typically consensual institutions in the Criminal Code adopted in $1997^{10}$ and the Criminal Procedure Code. ${ }^{11}$

\section{CONDITIONAL DISCONTINUANCE OF CRIMINAL PROCEEDINGS IN THE NEW CRIMINAL CODIFICATIONS OF 1997}

Were there, in the course of work on new criminal legislation in the 1990s, any proposals to give up conditional discontinuance considered as an instrument of penal policy in cases of

9 J. Skupiński, Warunkowe umorzenie..., op. cit. p. 23.

10 Ustawa z dnia 6 czerwca 1997 r. Kodeks karny, (t.j. Dz.U. z 2018 r., poz.1987) [Act of 6 June 1997, Criminal Code (consolidated text Journal of Laws of 2018, item 1987], hereinafter referred to as the CC of 1997 or CC.

11 Ustawa z dnia 6 czerwca 1997 r. Kodeks postępowania karnego, (t.j. Dz.U. z 2016 r., poz.1137) [Act of 6 June 1997, Criminal Procedure Code (consolidated text Journal of Laws of 2018, item 1137], hereinafter referred to as the CPC of 1997 or CPC. 
non-depraved perpetrators and in relation to deeds of minor importance? Definitely not. Quite the contrary, steps were taken to improve this institution and extend its normative form by adopting procedural regulations. The form of the substantive-legal aspect of conditional discontinuance was also modified. This involved an extension of legal bases for the application of conditional discontinuance, with a simultaneous specification, already in the criminal statute, that it was a non-custodial measure related to subjecting the perpetrator to a probation. It is an important change, because since the appearance of conditional discontinuance in the Polish law there has been a dispute among scholars about the nature of this measure - whether substantive, procedural or mixed (substantive and procedural). ${ }^{12}$ The obvious reason for this dispute unresolved until the entry into force of the new regulations was the aforementioned dual (hybrid) legal regulation.

What changes were introduced in the new provisions and were these changes the result of nearly 30 years of experience in the application of conditional discontinuance of criminal proceedings? Such a question should be answered "yes" at least in part.

The preconditions for conditional discontinuance of proceedings contained in Article 66 of the Criminal Code of 1997 have changed slightly in comparison with the previous regulations, although the essential elements of this institution and its normative essence remained. Under the legislation currently in force, criminal proceedings may be conditionally discontinued if the if the guilt and social consequences of the act are not significant, the circumstances of its commission do not raise doubts, and the attitude of the perpetrator not punished for an intentional criminal offence, his personal characteristics and his way of life to date provide reasonable grounds for the assumption that even in the event of the discontinuance of the proceedings, he will observe the legal order and particularly that he will not commit an offence (Article $66 \S 1$ of the Criminal Code of 1997).

Despite significant similarities in the regulation of the institution of conditional discontinuance of proceedings, several fundamental differences can be observed in both legal arrangements. The changes in the new regulation resulted from both the evaluation of the practice of conditional discontinuance for over a quarter of a century of application of the Criminal Code of 1969 and the change in the punishment policy by the legislature, with the latter element seeming to come to the fore.

While under the previously applicable legislation the proceedings could be conditionally discontinued only in respect of a perpetrator who had not previously been convicted of a crime, currently the institution of conditional discontinuance of proceedings is provided not only for first-time offenders (Article $66 \$ 1$ of the Criminal Procedure Code of 1997). The conditional discontinuance may also be applied to a person previously convicted of an unintentional crime. It is only important that the perpetrator was not punished for an intentional crime before. Interestingly, according to the Polish Supreme Court's jurisprudence, the condition of "not having been convicted for an intentional crime" under Article $66 \S 1$ of the Criminal Code applies only to final convictions that took place up to the date of decision on conditional discontinuance of proceedings. ${ }^{13}$ In other words, the conviction of a defendant for an intentional

12 Z. Świda, Uwagi o warunkowym umorzeniu postępowania karnego, (in:) Współzależność prawa karnego materialnego i procesowego (eds.) Z. Ćwiąkalski; G. Artymiak), Warszawa 2009, pp. 261-269. 
crime, in a situation where the ruling of the court has not yet become final, does not prevent the application of conditional discontinuance of proceedings for a new deed covered by the proceedings pending.

The legislature provided for a significant exception to the rule of non-punishment for an intentional crime as grounds for conditional discontinuance, contained in the Act on Counteracting Drug Addiction. ${ }^{14}$ This concerns both addicts ${ }^{15}$ and users of harmful psychoactive substances, who have been charged with committing an offence related to the use of an intoxicant, a psychotropic substance or a novel psychoactive substance, which is punishable by imprisonment of up to 5 years. Pursuant to Article 72 (4) of the Act, proceedings may also be conditionally discontinued in respect of a repeat offender (i.e. one who has previously been convicted of an intentional crime) if, prior to the sentence being passed, the offender undergoes a treatment, rehabilitation or participation in an educational and preventive programme run by an authorised medical provider or another healthcare institution. The introduction of this exception into the Polish criminal law should be derived primarily from the axiology of the Act on Counteracting Drug Addiction, differing from that of the Criminal Code. The aim of the regulations contained in this Act is primarily to prevent addiction and treat persons addicted to psychoactive substances, and therefore punishing for the use of psychoactive substances is of a secondary nature. The prospect of conditional discontinuance of proceedings is intended to encourage the offender to undertake drug treatment or preventive therapy to prevent addiction.

In comparison with the provisions of the Criminal Code of 1969, the current Criminal Code substantially increased the limit of the statutory penalty range for which conditional discontinuance of criminal proceedings is admissible. Currently, the conditional discontinuance can be applied to a perpetrator of a criminal offence punishable with a penalty of up to 5 years of imprisonment (previously up to 3 years of imprisonment) so that it is possible to use the institution in relation to a much larger number of crimes (and perpetrators) than before.

In the new Criminal Code the period of probation was extended to the period from one year to three years (Article $67 \S 1$ ), which should be related mainly to the increase of the statutory range of penalty for the offences in respect of which conditional discontinuance of proceedings is admissible. These types of criminal offences include as serious ones as: abduction or detention of a minor under 15 years of age or a vulnerable person because of his or her psychological or physical condition (Article 211 of the Criminal Code), storage, possession or access to a pornographic content involving a minor (Article $202 \S 4 \mathrm{a}$ of the Criminal Code), preparation for trafficking in human beings (Article 189a $\S 2$ of the Criminal Code), depriving a human of liberty (Article $189 \S 1$ of the Criminal Code), intentional harm to health, if the injury or damage to the victim's health lasted longer than 7 days (Article $157 \S 1$ of the Criminal Code), forgery of a document (including money) (Article $270 \S 1$ of the Criminal Code), ordinary theft (Article 278 of the Criminal Code).

14 Ustawa z dnia 29 lipca 2005 r. o przeciwdziałaniu narkomanii, (t.j. Dz.U. z 2019 r., poz. 852) [Act of 29 July 2005 on Counteracting Drug Addiction (consolidated text Journal of Laws of 2019, item 852)].

15 According to the statutory definition contained in the Act on Counteracting Drug Addiction (Article 4 (15)), an addict is a person who, as a result of the use of intoxicants, psychotropic substances, substitutes thereof or novel psychoactive substances, or their use for medical purposes, is in a state of addiction to these agents or substances. 
As the established scholarly opinion of the Polish criminal procedure puts it, the probation period is primarily intended for verification of the criminological forecast about the perpetrator at the time of the decision, as well as the disciplinary and educational consequences, which may be strengthened in particular by enriching the conditional discontinuance with surveillance or additional duties. The higher the assessment of the existing way of life, the attitude and personal characteristics of the perpetrator, the shorter the period of probation. However, where the assessment of the above circumstances is not that high, there may be a need to determine a longer period of probation in order to better consolidate the socially desirable attitudes in the perpetrator. Therefore, the period should be correlated with the nature of the duties imposed on the perpetrator, so that they exert their educational effect. The assessment is strictly individual and depends on the specificity of the case and the characteristics of the perpetrator. ${ }^{16}$ This, on the other hand, indicates a certain flexibility in the use of conditional discontinuance as a means of criminal response, especially since it is possible during the probation period to modify the obligations imposed on the perpetrator and their replacement with other than imposed originally.

In the currently applicable Criminal Code, the possibility of bundling the conditional discontinuance decision with a guarantee granted by an authorised entity were cancelled. Instead, a provision was introduced whereby the court may, during the period of probation, place the perpetrator under the supervision of a probation officer or a person of public trust, an association or community organisation whose activities include educational care, preventing the demoralisation of or providing assistance to sentenced persons (Article $67 \S 2$ of the Criminal Code). First and foremost, the supervisor is obliged to ensure that the person in respect of whom the proceedings have been conditionally discontinued complies with the legal order during the period of probation and, above all, does not commit the offence again, as well as performs the obligations imposed on him or her by the court. The manner in which this obligation is to be performed is beyond the sphere of criminal law (except for the supervision by a probation officer, whose duties are determined statutorily) and depends largely on the nature of the relationship between the supervising person and the perpetrator, and even the power of personal authority of the person exercising the supervision whose task is influencing the behaviour of the perpetrator. The advantage of such a solution is the possibility of influencing more effectively the offender in an informal manner, as well as the shifting of the cost of supervision from the State Treasury to the supervising entity.

The currently applicable Criminal Code has slightly modified the rules for imposing obligations on the perpetrator for whom the proceedings have been conditionally discontinued. Firstly, the compulsory imposition of an obligation to remedy the damage in whole or in part (in the previous Code such an obligation was optionally imposed) and, where possible, also the obligation to compensate for the personal injury suffered. ${ }^{17}$ If the court does not impose an obligation to remedy the damage (for example, because it is not possible to determine its

16 T. Kozioł, Warunkowe umorzenie postępowania karnego, Warszawa 2009, chapter IV, point 2.

17 In Polish law, there is traditionally a distinction between the damage for which a remedy may be claimed, and the personal injury for which a pain and suffering compensation may be claimed. In general, the damage is the difference between what the victim would have had if there had been no event causing the damage and what he had as a result of it. The damage is of a property nature (e.g. damage resulted from the destruction of property of a certain value), while the personal injury is of a non-material nature (e.g. due to insulting the victim or deprivation of liberty). Cf:: A. Szpunar, Zadośćuczynienie za szkodę niemajątkowa, Bydgoszcz 1999, p. 66 et seq. 
amount), it must, in return, obligatorily impose vindictive damages. When subjecting the perpetrator to probation, the Court may also impose obligations on the perpetrator by:

1. Informing the court or probation officer on the course of the probation period;

2. An apology to the victim;

3. The performance of the maintenance obligations imposed on the perpetrator;

4. Refraining from abusing alcohol or using other intoxicants;

5. Undergoing an addiction therapy;

6. Undergoing a therapy, in particular a psychotherapy or psychoeducation,

7. Participation in corrective and educational activities;

8. Refraining from contacting the victim or other persons in a certain way or approaching the victim or other persons at a distance determined by the court;

9. Leaving the premises occupied jointly with the victim.

It is also permissible to rule on a pecuniary benefit or a driving ban for up to 2 years. The imposition of an obligation to undergo an addiction therapy or other therapy may only take place with the consent of the perpetrator (Article $67 \S 3$ and 4 of the Criminal Code). The nature of the obligations determined by the court depends on the specificities of the case, as well as the criminological forecast, i.e. the assessment of the perpetrator's behaviour, especially in the context of the likelihood of committing a new crime. A greater risk of recidivism will result in a broader catalogue of obligations imposed on the offender, as well as a longer probation period.

However, the most important, even fundamental change, as compared to the original regulation, which was introduced in the Criminal Procedure Code of 1997 in the procedural part of the regulation of conditional discontinuance was the transfer of the power to issue decision on conditional discontinuance (and therefore the application of a criminal response measure against a committed offence) to courts. The prosecutor, under previous regulations authorised to apply conditional discontinuance, adjudicate on the probation period, obligations of the perpetrator and the appointment of a probation officer for the perpetrator, was completely deprived of the right to decide on the conditional discontinuance of proceedings. It was undoubtedly the right solution, since the decision on conditional discontinuance is of a substantive nature, it breaks the presumption of innocence, and this measure as a substantive penal measure instrument can only be used against a perpetrator who has committed a criminal act beyond question, constituting a response to this act. Currently, only the court in trial proceedings may conditionally discontinue criminal proceedings. The conditional discontinuance of criminal proceedings requires issuing a judgement (the so-called judgement on conditional discontinuance of criminal proceedings). The prosecutor (as well as other public prosecuting attorneys) is only entitled to submit a request for conditional discontinuance (Article 336 of the Criminal Procedure Code). It should be noted, however, that the court may conditionally discontinue the proceedings also upon the initiative of the defendant included in the response to the indictment, or defendant's application for conviction without a trial (Article 338a of the Criminal Procedure Code) and even ex officio when the court finds that the defendant committed the act. 
The elimination of the prosecutor from the circle of entities authorised to decide on conditional discontinuance of criminal proceedings and the transfer of the powers to decide on the application of this measure to the jurisdiction of the court made it necessary to extend the existing regulation of the procedural part of this legal institution. It became necessary to specify who may apply to the court for conditional discontinuance, what form the application should take and what are the formal conditions for it to be filed in effectively. In view of the change in regulations as regards the forum for substantive adjudication by the court and the introduction of the possibility of adjudicating (ruling) on the merits outside the main hearing, at the so-called judgement-issuing session, the legislature also had to provide for a procedure for the application of conditional discontinuance. If it is the public prosecutor who files with the court a request to apply conditional discontinuance, a special procedure is launched, the essence of which is to issue a judgement on conditional discontinuance of the criminal proceedings at a judgement-issuance hearing without holding a trial and taking evidence. The application of conditional discontinuance of criminal proceedings is not currently (under the Criminal Procedure Code of 1997) treated as an institution constituting an expression of the principle of opportunism. The adopted solution consisting in the creation of a judicial manner of adjudicating on conditional discontinuance ultimately determined the substantive-law character of this institution as a means of penal-law response applied to perpetrators of minor crimes.

The procedural regulations of the institution of conditional discontinuance of proceedings have been significantly extended in the currently applicable Criminal Procedure Code. ${ }^{18}$ First of all, the forum for adjudicating on conditional discontinuance was defined, which is, as a rule, a court session (the so-called session on the issuance of judgement, as opposed to hearing preparatory sessions and sessions held outside the hearing to decide on incidental issues, e.g. on the application or repeal of a preventive measure if these decisions were not taken at the hearing), thanks to which the hearing can be avoided at all, which significantly streamlines the proceedings and reduces the costs of proceedings. The legislature has also decided that conditional discontinuance of proceedings can only be achieved by way of a judgement. This was the result of the decision of the Polish Constitutional Tribunal, which decided in its ruling of 16 May $2000^{19}$ that the presumption of innocence may be broken only in a judgement, and therefore the decision on conditional discontinuance of criminal proceedings (initially provided for by the legislature in relation to the use of conditional discontinuance) does not meet the constitutional standard set forth in Article 42(3) of the Constitution of the Republic of Poland. ${ }^{20}$ However, the change in the legislation in force took place only as a result of the amendment to the Criminal Procedure Code in $2003,{ }^{21}$ since which the court, either at a judgement-issuance

18 Art. 336 CPC, art. 341-342 CPC, art. 414 CPC, art. 422 \$1 CPC, art. $444 \S 1$ CPC, art. 549-551 CPC.

19 Wyrok Trybunału Konstytucyjnego z dnia 16 maja 2000 r., sygn. akt P1/99, Prokuratura i Prawo 2000, no. 9, Dodatek Orzecznictwo, pp. 38-58.

20 Article 42 (3) of the Polish Constitution states that everyone shall be presumed innocent of a charge until his guilt is determined by the final judgment of a court; E. Skrętowicz, Charakter prawny orzeczenia warunkowo umarzającego postępowanie karne $w$ świetle zasady domniemania niewinności, (in:) S. Stachowiak (ed.) Współczesny polski proces karny. Księga ofiarowana profesorowi Tadeuszowi Nowakowi, Poznań 2002, pp. 19-22; A. Wąsek, Krytyczne uwagi do wyroku Trybunału Konstytucyjnego z dnia 16 maja 2000 (P1/99) dotyczace warunkowego umorzenia postepowania karnego, (in:) S. Stachowiak (ed.) Współczesny polskiego..., op. cit. pp. 23-34.

21 Ustawa z dnia 10. 01. 2003 r. o zmianie ustawy - Kodeks postępowania karnego, ustawy - Przepisy wprowadzające Kodeks postępowania karnego, ustawy o świadku koronnym oraz ustawy o ochronie informacji niejawnych, Dz. U. z 2003 r., nr 17, 
hearing or trial, rules on the conditional discontinuance of criminal proceedings. A person, with regard to whom the prosecutor applied to the court for conditional discontinuance of proceedings, has the procedural status of the accused (Article 71 of the Criminal Procedure Code), and the prosecutor's request for conditional discontinuance is deemed a substitute for the indictment. Conditional discontinuance is not a conviction, but the application of a non-custodial penal measure combined with imposing obligations and applying a period of probation. If the perpetrator fails to comply with his obligations or violates the legal order during the probation period ${ }^{22}$ or within six months after the probation period, the criminal proceedings conditionally discontinued with a judgement are to be resumed and conducted anew under general rules, ${ }^{23}$ and the court rules on the liability of the accused for the offence he was charged of in the request for conditional discontinuance or the indictment. In accordance with the principle of accusatorial procedure, the court may decide in this case because it has a procedural petition submitted by the public prosecutor. This petition is either a request for conditional discontinuance or an indictment. The court independently decides whether to conditionally discontinue the proceedings conducted anew (i.e. apply this non-custodial penal measure again) or to convict or acquit the perpetrator. If the conditionally discontinued proceeding is not resumed within 6 months of the end of the probation period, the discontinuance is final and the perpetrator may not be held criminally liable for the offence committed.

\section{CONDITIONAL DISCONTINUANCE OF CRIMINAL PROCEEDINGS - THE CURRENT PICTURE}

The penal-procedural literature stresses that the expansion of procedural regulations on conditional discontinuance of proceedings strengthens the courts' tendency to decide on the merits outside the main hearing (i.e. a hearing before the court of first instance). At the same time, these changes are in line with a broader trend of transformation of the Polish criminal procedure, involving the creation of "fast tracks" for adjudicating on the issue of criminal liability of an offender for an alleged offence, in the consensual path, i.e. conviction without trial (Article $335 \S 1$ and 2 CPC, Article 338a CPC), voluntary submission to punishment (Article 387 (PC). In all cases, both with regard to conditional discontinuance of proceedings and conviction outside a trial hearing, not only is it a matter of issuing a judgement at a non-trial session, but also the issue of participation of the parties in the judgement-issuance session (including the victim who is not a party with the right to participate in such a session), the order of procedural activities, the form of a decision concluding the proceedings, the question

poz. 155 [Act of 10. 01. 2003 on the amendment of the Act: Criminal Procedure Code, the Act: Introductory provisions to the Criminal Procedure Code, the Act on the protected witness and the Act on the protection of classified information, Journal of Laws of 2003, no. 17, item 155]).

22 Article 68 of the Criminal Code provides for grounds for resuming conditionally discontinued proceedings; they may result in mandatory resumption of the proceedings (committing during the probation period an intentional offence for which the probated offender was finally convicted) or an optional resumption (a gross infringement of the legal order, in particular the commission of a criminal offence other than that which constitutes the basis for the mandatory resumption of proceedings, evading supervision or failure to perform the obligation or penal measure imposed, compensation or forfeiture, or failure to comply with a settlement with the victim. 
of the defendant's consent or at least acceptance for a specific court's decision, basing the decision on evidence presented in pre-trial proceedings (i.e. giving up the adversarial character of the procedure) has been similarly shaped by the Polish legislature. ${ }^{24}$

In this regard, it is noted that under the new legislation, the percentage of cases of conditional discontinuance of criminal proceedings in relation to the number of total convictions has increased (see table). This is worth noting, since the new possibilities for consensual settlement of criminal liability, for minor acts and quite serious acts, could naturally constitute a kind of competition for the use of conditional discontinuance, for example because the conditional discontinuance of proceedings results in the need of monitoring the offender during the period of probation and verification of the educational impact of the measure applied.

Table: Conditional discontinuance of criminal proceedings in the period 2005-2016. ${ }^{25}$

\begin{tabular}{|c|c|c|c|}
\hline Year & $\begin{array}{c}\text { Number of sentences } \\
\text { (in absolute numbers) }\end{array}$ & $\begin{array}{c}\text { Number of conditionally } \\
\text { discontinued cases } \\
\text { (in absolute numbers) }\end{array}$ & $\begin{array}{c}\text { \% of } \\
\text { convictions }\end{array}$ \\
\hline 2005 & 515,822 & 30,364 & 5.88 \\
\hline 2010 & 420,810 & 24,913 & 5.92 \\
\hline 2012 & 408,107 & 30,732 & 7.53 \\
\hline 2013 & 353,208 & 29,710 & 8.41 \\
\hline 2014 & 295,353 & 26,022 & 8.81 \\
\hline 2015 & 260,034 & 24,609 & 9.46 \\
\hline 2016 & 289,512 & 30,678 & 10.59 \\
\hline
\end{tabular}

Source: own study

According to the data presented in the table above, in the last 15 years, the number of conditionally discontinued cases has been relatively stable (with a slight decline between 2010 and 2015, which was due to other reforms of the justice system). However, the comparison of the percentage of cases of conditional discontinuance in relation to the total number of convictions leads to completely different result. While in 2005 judgements on conditional discontinuance accounted for only less than $6 \%$ of the judgements in respect of the number of convictions, 11 years later the proportion of conditionally discontinued cases amounted to $10.59 \%$ and it was so despite the aforementioned "competition" in the form of consensual forms of adjudication, such as a conviction without a trial hearing (Article 335 CPC) and voluntary submission to punishment (Article 387 CPC) present in Polish procedural criminal law since 1997. It can therefore be concluded that although the importance of conditional discontinuance of criminal proceedings, it is not marginalised.

24 H. Paluszkiewicz, Refleksje o perspektywach rozwoju..., op. cit., p. 386, see also: S. C. Thaman, Comparative Criminal Procedure. A Casebook Approach, Carolina Academic Press, North Carolina, USA, 2002, p. 162.

25 Own study based on Rocznik Statystyczny Rzeczpospolitej Polskiej, Warszawa 2017, p. 32 and Statystyka Sądowa. Prawomocne skazania osób dorostych 2012 - 2016, Departament Strategii i Funduszy Europejskich, Warszawa 2017, p. 13. 
Remaining in the system of criminal law, the conditional discontinuance as a non-custodial penal measure related to subjecting the perpetrator to probation, and expanding the procedural regulation relating to its application, the legislature saw the need to embrace new trends in penal policy and, above all, to increase the influence of the defendant and other participants in the criminal procedure on the judgement issued by the court. ${ }^{26}$ This growth of the idea of consensual resolution of criminal cases, which eventually resulted in the development of two methods of resolving criminal cases - consensual one (out of a trial hearing) and adversarial one (at a trial hearing) has resulted in the decision on conditional discontinuance could remain on the periphery of the judicial practice, despite its obvious advantages, such as e.g. educational.

Table: Number of persons sentenced under the consensual method in the period 2012-2018 27

\begin{tabular}{|l|c|c|c|c|c|c|c|}
\hline \multicolumn{1}{|c|}{ Year } & $\mathbf{2 0 1 2}$ & $\mathbf{2 0 1 3}$ & $\mathbf{2 0 1 4}$ & $\mathbf{2 0 1 5}$ & $\mathbf{2 0 1 6}$ & $\mathbf{2 0 1 7}$ & $\mathbf{2 0 1 8}$ \\
\hline $\begin{array}{l}\text { Total number of } \\
\text { convicts }\end{array}$ & 413,263 & 374,691 & 322,703 & 286,472 & 276,588 & 261,408 & 277,974 \\
\hline $\begin{array}{l}\text { Number of persons } \\
\text { convicted under } \\
\text { consensual method }\end{array}$ & 213,477 & 181,690 & 151,191 & 140,615 & 144,034 & 102,800 & 91,076 \\
\hline $\begin{array}{l}\text { Percentage of } \\
\text { convictions }\end{array}$ & 51.65 & 48.49 & 46.85 & 49.08 & 52.07 & 39.32 & 32.76 \\
\hline
\end{tabular}

Source: own study

However, the strive towards shortening the procedure of adjudication on the merits, which resulted in the interest in the practice of consensual forms (conviction without a trial hearing, conviction without evidence-taking process, conviction at the request of the defendant) did not eliminate the use of conditional discontinuance. Conditional discontinuance of criminal proceedings is an extremely valuable means of the criminal-law response to small-scale crime, which avoids stigmatising the offender and offers him a chance to get back to normal life in society, but so broad interest among the judiciary in consensual forms of settlement of criminal cases has resulted in the courts far less likely to use that institution, while preferring the institution of conviction without a trial hearing as a quick form of ruling on the criminal liability of the offender who does not challenge the fault and the perpetration, guaranteeing the victim to remedy the damage inflicted on him or her.

How, against this background, does the prospect of conditional discontinuance look as an institution of criminal law in a broad sense?

It seems that normative changes in terms of conditional discontinuance are not necessary for both the substantive and procedural parts of the regulation. The normative shape of the measure is appropriate - it takes into account both the current requirements and the trends in criminalisation and provides for proper procedural guarantees for the defendant. Through

26 H. Paluszkiewicz, Refleksje o perspektywach rozwoju..., p. 383.

27 Own study based on PK-P1K Sprawozdania z działalności powszechnych jednostek organizacyjnych prokuratury w sprawach karnych za lata 2012, 2013, 2014, 2015, 2016, 2017, 2018, www.pk.gov.pl. 
the possibility of imposition and modification of obligations during the period of probation, it is a flexible correctional means and prevents the defendant from breaching the law again. It also ensures that the damage suffered by the victim is remedied, which restores the situation undermined by the prohibited act. It is therefore a non-custodian penal measure related to the subjecting the offender to probation by means of the potential of an adequate penal response. The procedure for the application of conditional discontinuance and extensive possibilities to rule on it outside the trial hearing also meets the postulate of promptness of criminal proceedings. In a judgement that conditionally discontinues the criminal proceedings, the court precisely determines the act the accused is charged of, its legal classification, and determines the probation period, ${ }^{28}$ which results in that the offender covered by this penal measure is not found guilty (conviction) in this case. Thus, there is no negative consequence of conviction while maintaining a criminal-law response, quite severe one, to this prohibited act and compensation or remedy for damage to the victim.

The problem is, however, the question of the state's penal policy and the popularization of conditional discontinuance as a means of penal response with high educational qualities, the application of which in practice is not complicated and requires neither specific procedural activities nor lengthy evidence-taking procedure. The only thing that is necessary is the prosecution authorities' determination to apply to the court for the conditional discontinuance and to convince the courts that the judgement on conditional discontinuance of criminal proceedings for the period of probation, with the imposition on the perpetrator of relevant obligations, including remedying the damage is an appropriate instrument of the current penal policy, which should be chosen from among other forms of penal response when deciding on the liability of non-depraved perpetrators of minor offences.

\section{REFERENCES}

1. Gerecka - Żołyńska, A.; Mazur, P.; Paluszkiewicz, H., Kilka uwag o instytucji warunkowego umorzenia postępowania karnego na tle jej zwiq̨zków z prawem materialnym i formalnym, (in:) Współzależność prawa karnego materialnego i procesowego (eds.) Z. Ćwiąkalski; G.Artymiak, Warszawa 2009, p. 274.

2. Juszka, K., Geneza instytucji warunkowego umorzenia postępowania karnego, Studia Prawno-ekonomiczne, 2019, no. 46, pp. 25-39.

3. Kozioł, T., Warunkowe umorzenie postępowania karnego, Warszawa 2009, chapter IV, point 2

4. Kunicka-Michalska, B., Warunkowe umorzenie postępowania karnego w latach 1970 - 1977, Warszawa 1982, p. 97.

5. Leonieni, M., Michalski, W.,Warunkowe umorzenie postepowania karnego w świetle ustawy i praktyki sq̨dowej, Warszawa 1972, p. 18.

6. Marek, A., Istota i skutki warunkowego umorzenia postępowania, Państwo i Prawo 1970, vol. 12, p. 948.

28 As set out in Article 342(1) CPC in wording applicable as of 5 October 2019 (amendment made by Ustawa z dnia 19 lipca 2019 r. o zmianie Ustawy Kodeks postępowania karnego i niektórych innych ustaw, Dz.U. z 2019 r. poz.1694 [Act of 19 July 2019 amending the Criminal Procedure Code and certain other laws; Journal of Laws of 2019, item 1694]). 
7. Marek, A., Warunkowe umorzenie postępowania karnego, Warszawa 1973.

8. Paluszkiewicz, H., Ewolucja instytucji warunkowego umorzenia postępowania karnego w prawie polskim, Czasopismo Prawno-Historyczne 2008, no. 1, pp. 139-161.

9. Paluszkiewicz, H., Refleksje o perspektywach rozwoju karnoprocesowej regulacji warunkowego umorzenia postępowania karnego, (in) Reforma prawa karnego. Propozycje i komentarze. Księga pamiątkowa Profesor Barbary Kunickiej-Michalskiej, eds J. Jakubowska-Hara; C. Nowak; J. Skupiński, Warszawa 2008, p. 381.

10. Rocznik Statystyczny Rzeczpospolitej Polskiej, Warszawa 2017, p. 32.

11. Skrętowicz, E.,Charakter prawny orzeczenia warunkowo umarzajacego postępowanie karne $w$ świetle zasady domniemania niewinności, (in:) S. Stachowiak (ed.) Współczesny polski proces karny. Księga ofiarowana profesorowi Tadeuszowi Nowakowi, Poznań 2002, pp. 19-22.

12. Skupiński, J., Warunkowe umorzenie postępowania karnego jako środek polityki karnej prokuratorów $i$ sq̨dów, Studia Prawnicze, 1991, no. 2, p. 23.

13. Statystyka Sq̨dowa. Prawomocne skazania osób dorostych 2012 - 2016, Departament Strategii i Funduszy Europejskich, Warszawa 2017, p. 13.

14. Szpunar, A., Zadośćuczynienie za szkodę niemajątkowq, Bydgoszcz 1999, p. 66 et seq.

15. Świda, Z., Uwagi o warunkowym umorzeniu postępowania karnego, (in:) Współzależność prawa karnego materialnego i procesowego (eds.) Z. Ćwiąkalski, G. Artymiak), Warszawa 2009, pp. 261-269.

16. Thaman, S. C., Comparative Criminal Procedure. A Casebook Aproach, Carolina Academic Press, North Carolina, USA, 2002, p. 162.

17. Tobis, A., Z rozważań nad istotą warunkowego umorzenia postępowania karnego, Ruch Prawniczy Ekonomiczny i Socjologiczny 1974, no. 4, p. 135.

18. Wąsek, A., Krytyczne uwagi do wyroku Trybunału Konstytucyjnego z dnia 16 maja 2000 (P1/99) dotyczq̨ce warunkowego umorzenia postepowania karnego, (in: ) S. Stachowiak (ed.) Współczesny polski proces karny. Księga ofiarowana profesorowi Tadeuszowi Nowakowi, Poznań 2002, pp. 23-34.

19. Zoll, A. Materialnoprawna problematyka warunkowego umorzenia postępowania, Zeszyty Naukowe Uniwersytetu Jagiellońskiego, Prace Prawnicze 1973, no. 62, pp. 10-31.

\section{LIST OF REGULATIONS, ACTS AND COURT DECISIONS}

1. Ustawa z dnia 19 kwietnia 1969 r. Kodeks karny (Dz.U. z 1969 r., Nr 13, poz. 94), [Act of 19 April 1969, Criminal Code (Journal of Laws 1969, No. 13, item 94),

2. Ustawa z dnia 19 kwietnia 1969 r. Kodeks postępowania karnego (Dz.U. z 1969 r., Nr 13, poz. 96), [Act of 19 April 1969, Criminal Procedure Code (Journal of Laws 1969, No. 13, item 96),

3. Ustawa z dnia 6 czerwca 1997 r. Kodeks karny, (t.j. Dz.U. z 2018 r., poz.1987) [Act of 6 June 1997, Criminal Code (consolidated text Journal of Laws of 2018, item 1987],

4. Ustawa z dnia 6 czerwca 1997 r. Kodeks postępowania karnego, (t.j. Dz.U. z 2016 r., poz.1137) [Act of 6 June 1997, Criminal Procedure Code (consolidated text Journal of Laws of 2018, item 1137],

5. Ustawa z dnia 10.01.2003 r. o zmianie ustawy - Kodeks postępowania karnego, ustawy - Przepisy wprowadzające Kodeks postępowania karnego, ustawy o świadku koronnym oraz ustawy o ochronie informacji niejawnych, Dz. U. z 2003 r., nr 17, poz. 155 [Act of 10. 01.2003 on the amendment of the Act: Criminal Procedure Code, the Act: Introductory provisions to the Criminal Procedure Code, 
the Act on the protected witness and the Act on the protection of classified information, Journal of Laws of 2003, no. 17, item 155]).

6. Ustawa z dnia 29 lipca 2005 r. o przeciwdziałaniu narkomanii, (t.j. Dz.U. z 2019 r., poz. 852) [Act of 29 July 2005 on Counteracting Drug Addiction (consolidated text Journal of Laws of 2019, item 852)].

7. Ustawa z dnia 19 lipca 2019 r. o zmianie Ustawy Kodeks postępowania karnego i niektórych innych ustaw, Dz.U. z 2019 r. poz.1694 [Act of 19 July 2019 amending the Criminal Procedure Code and certain other laws; Journal of Laws of 2019, item 1694]).

8. Judgment of the Trybunał Konstytucyjny of 16 May 2000, case ref. no. P1/99, Prokuratura i Prawo 2000, no. 9, Dodatek Orzecznictwo, pp. 38-58.

9. Judgement of the Supreme Court of 17 May 2016, case ref. no. III KK 28/16, LEX no. 2051033.

\section{WEBSITE REFERENCES}

1. PK-P1K Sprawozdania $z$ działalności powszechnych jednostek organizacyjnych prokuratury $w$ sprawach karnych za lata 2012, 2013, 2014, 2015, 2016, 2017, 2018, www.pk.gov.pl. Accessed 1 July 2019. 


\section{UVJETNI ODUSTANAK OD KAZNENOG POSTUPKA U POLJSKOM PRAVNOM SUSTAVU - PEDESETOGODIŠNJA ISKUSTVA I PROCJENA DALJNJEG RAZVOJA}

\section{Sažetak}

Predmet je ovoga rada analiza pitanje uvjetnog odustanka od kaznenog postupka u poljskom pravnom sustavu. Rasprava se odnosi na normativnu prirodu ove mjere kažnjavanja, hibridnu pravnu regulaciju i razvoj tijekom 50 godina njezine primjene. U analizi se uzima u obzir trenutačno stanje vezano za poljski kazneni postupak i pozicija uvjetnog odustanka kao instrumenta kaznene politike s obzirom na sve veću važnosti konsenzualnih oblika postupanja u kaznenom postupku. Rad se prije svega bavi pitanjem uređenja postupka uvjetnog odustanka prema poljskom Zakonu o kaznenom postupku. Poljsko iskustvo u primjeni uvjetnog odustanka kao instrumenta kaznene politike protiv počinitelja manjih prijestupa, postupka koji ne demoralizira, koji ima pozitivne ishode, pokazuje da se institut potvrdio te da bi njegova šira primjena u pravosudnoj praksi bila korisna. U radu se raspravlja o mogućnostima intenziviranja primjene uvjetnog odustanka kao mjere koja se zahvaljujući modernom materijalnom i postupovnom kaznenom zakonodavstvu dokazala kao mjera primjenjiva za suzbijanje kriminala.

Ključne riječi: $\quad$ uvjetni odustanak od kaznenog postupka, poljsko kazneno pravo, konsenzualno donošenje odluka u kaznenim stvarima, kaznene mjere koje ne uključuju oduzimanje slobode

\section{(c) (1) (5)}

This work is licensed under a Creative Commons

Attribution-NonCommercial 4.0 International License.

* Dr. sc. Hanna Paluszkiewicz, prof. dr. hab. na Fakultetu za pravo i upravu Sveučilišta u Zielonoj Gori, pl. Słowiański 9, 65-069 Zielona Góra, Poljska. E-adresa: h.paluszkiewicz@wpa.uz.zgora.pl. ORCID: https://orcid. org/0000-0001-5198-8360.

** Dr. sc. Katarzyna Dudka, prof. dr. hab. na Fakultetu za pravo i upravu Sveučilišta Maria Curie-Skłodowska u Lublinu, pl. Marii Curie-Skłodowskiej 5, 20-031 Lublin, Poljska. E-adresa: katarzyna.dudka@poczta.umcs. lublin.pl. ORCID: https://orcid. org/0000-0001-5598-5175. 